\title{
Characteristics of summer energy balance on the west coast of the Antarctic Peninsula
}

\author{
Matthias Braun, Christoph Sahneider \\ Institut für Physische Geographie, Universität Freiburg, Werderring 4, D-79085 Freiburg, Germany
}

\begin{abstract}
The characteristics of summer energy budgets in the ablation zones during the summer at the surface of two glaciers in the Antarctic Peninsula are investigated and compared to the findings of previous studies. The study areas are located on King George Island $\left(62^{\circ} \mathrm{S}\right)$ and in Marguerite Bay $\left(68^{\circ} \mathrm{S}\right)$. The summer energy balance was computed from automatic weather station data. The results reveal that turbulent heat fluxes dominate over radiation balance in Marguerite Bay, whereas on King George Island ablation is driven by net radiation. The summer energy balance on King George Island reflects the more maritime subpolar climate along the northwest tip of the peninsula in contrast to a more continentally toned polar climate in Marguerite Bay and areas further south. The terms of the energy balances are partitioned very differently, but advection from northerly directions causes the highest summer snowmelt rates at both study sites. It is concluded that sensitivity studies should consider not only the mean air-temperature increase, but also possible changes in other climate parameters.
\end{abstract}

\section{INTRODUCTION}

Glaciers along the Antarctic Peninsula are not linked to the great Antarctic ice sheets. They are much smaller and experience different climate conditions, undergoing considerable surface melting during the summer months. Consequently, they must be treated separately when glacier-climate interactions in Antarctica are considered.

Recent studies have reported warming trends on the Antarctic Peninsula of up to $0.67^{\circ} \mathrm{C}$ per decade during the last 40 years (e.g. King, 1994; Smith and others, 1996; Skvarca and others, 1998). The disintegration of ice shelves at all latitudes around the Antarctic Peninsula is regarded as further evidence of regional warming (e.g. Doake and others, 1998; Lucchitta and Rosanova, 1998; Rott and others, 1998). Fox and Cooper (1998) detected an extension of snow-free areas in northern Marguerite Bay during the last four decades. They also reported a sharp increase in the number of positive degree days in this area since the 1960s. Comparing reports given by Rundle (1970) and Casassa (1989), a shift towards a higher equilibrium-line altitude can be derived for Anvers Island. The same conclusion can be drawn for the South Shetland Islands from studies by Orheim and Govorukha (1982), M. Pourchet (personal communication, 1996), Simões and others (1999) and Braun and others (2000). In Marguerite Bay a study by Schneider (1998) suggests a similar tendency.

The mountain crest of the Antarctic Peninsula acts as a major obstacle in the circumpolar west-wind drift of the Southern Hemisphere. As a result, climate conditions along the Antarctic Peninsula are characterized by strong latitudinal and longitudinal gradients. Figure 1 shows the Antarctic Peninsula with overlaid isotherms after Reynolds (1981). In general, temperatures are approximately $8 \mathrm{~K}$ lower on the east coast than on the west coast of the peninsula. The difference in mean annual temperature between $62^{\circ} \mathrm{S}$ and $72^{\circ} \mathrm{S}$ exceeds $12 \mathrm{~K}$ on the east side of the mountain ridge and about $7 \mathrm{~K}$ on the west coast. The climate in the northern part of the Antarctic Peninsula and in the South Shetland Islands is dominated by a series of low-pressure systems, which leads to a highly maritime climate. Further south on

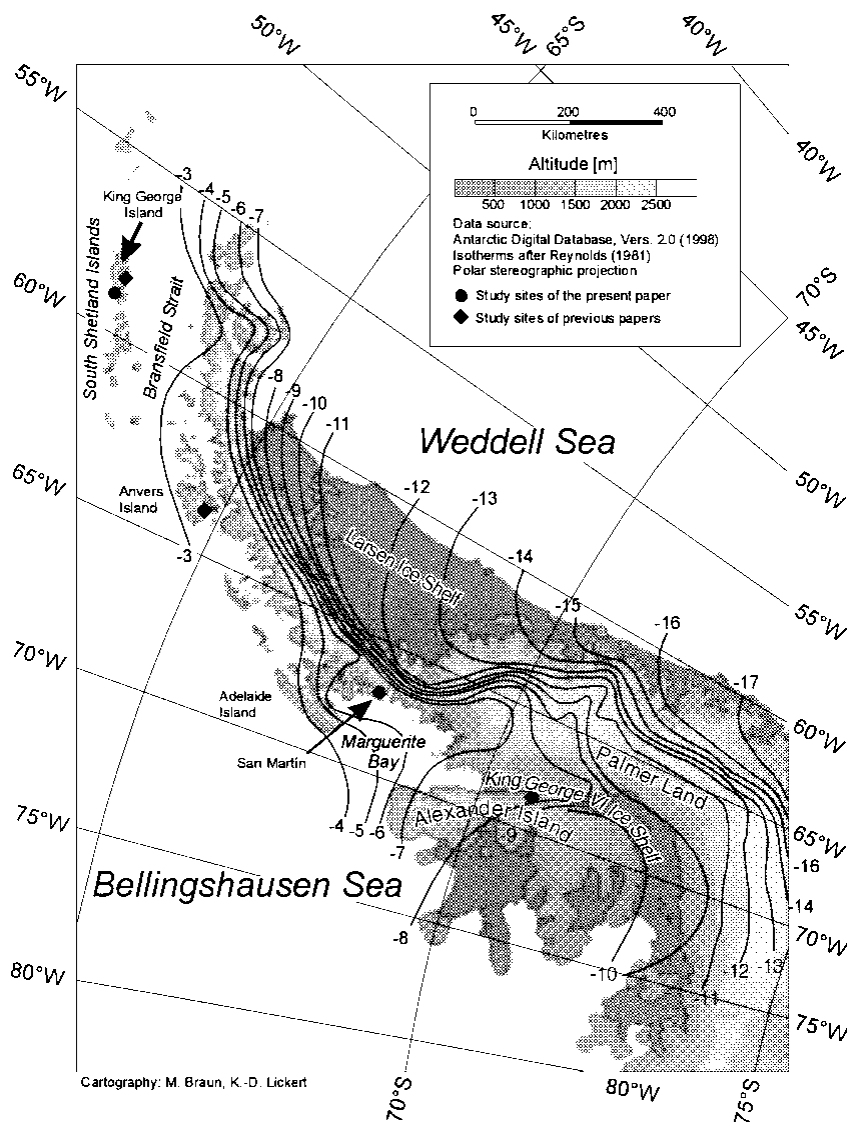

Fig. 1. Map of the Antarctic Peninsula with location of study sites. Isotherms after Reynolds (1981) are incorporated. 
the west coast, stable synoptic situations are reported more frequently (Pepper, 1954). The east-coast climate is characterized by frequent surface inversions and by the formation of cold barrier winds, occasionally reaching as far north as the South Shetland Islands (Schwerdtfeger, 1984).

This spatial climate variability suggests that differences in the surface-energy-balance terms and the resulting ablation should be expected. Since ablation is one of the terms that influence glacier mass-balance changes in the area, information on the present state of the regional pattern of snowmelt and its driving mechanisms is desirable.

The bulk aerodynamic method was used to compute the surface energy balance during the summer months at two sites $\left(62^{\circ}\right.$ and $\left.68^{\circ} \mathrm{S}\right)$ on the Antarctic Peninsula. The results are discussed in relation to the different regional climatic conditions at the two sites. Energy-balance studies previously carried out on the Antarctic Peninsula were used in the interpretation of our results. These studies include the contributions made to the International Hydrological Decade (1965-74) in 1973-74 on South Georgia (Hogg and others, 1982) and on Alexander Island (Jamieson and Wager, 1983). In addition, Bintanja (1995) presented a detailed energybalance study from Admiralty Bay on King George Island, and energy-balance estimates from Anvers Island are given in Casassa (1989).

\section{STUDY SITES}

\section{King George Island}

King George Island, $>90 \%$ ice-covered, is the largest of the South Shetland Islands. Its major ice cap is $0-679 \mathrm{~m}$ a.s.l., with approximately $40 \%$ of the ice-covered area below $250 \mathrm{~m}$ a.s.l. Mean air temperatures are positive during the summer months, and occasional snowmelt events can also occur during winter (Rachlewicz, 1997). Snowmelt generally starts in November at lower elevations (Braun and others, 2000) and lasts until March (Wen and others, 1998). Föhn effects are reported in Admiralty Bay, due to the frequent advection from the north and northwest. The mean annual air temperature at the south coast (Arctowski station: $-2.5^{\circ} \mathrm{C}$ ) is about $0.4 \mathrm{~K}$ higher than on the north coast (Bellingshausen: $-2.8^{\circ} \mathrm{C}$ ) (Martianov and Rakusa-Suszczewski, 1989). The study site for the energy-balance measurements is located on the northwest margin of the major ice cap $\left(62^{\circ} 09^{\prime} \mathrm{S}, 58^{\circ} 54^{\prime} \mathrm{W}\right.$; $85 \mathrm{~m}$ a.s.l.) in the vicinity of Fildes Peninsula.

\section{Marguerite Bay}

The second study area is situated near the Argentine base San Martín on Northeast Glacier $\left(68^{\circ} 07^{\prime} \mathrm{S}, 67^{\circ} 00^{\prime} \mathrm{W}\right.$; $120 \mathrm{~m}$ a.s.l.) in inner Marguerite Bay. This outlet glacier, which is widening at the ice cliff, forms a $20 \mathrm{~km}$ long valley glacier and is connected by a $1000 \mathrm{~m}$ high icefall with the plateau further inland. The Marguerite Bay climate is transitional between the moist, moderate climate in the north and the continental climate in the south and east (Schneider, 1998). Protected by the surrounding mountain ridges on Adelaide Island, on Alexander Island and on the Antarctic Peninsula, the area experiences twice as many sunny days as Anvers Island (Pepper, 1954). The mean annual temperature is $-5.7^{\circ} \mathrm{C}$ (Wunderle, 1996). The weather pattern is dominated by the alternation of warm airflow from the northeast, cyclones in the Bellingshausen Sea and cold air mass from the south. The gradient between low pressure on the west coast and high pressure on the east coast of the peninsula occasionally induces föhn-type gales with dry air masses from the Weddell Sea in the east.

\section{METHODOLOGY}

The energy balance for both test sites was computed from hourly mean values recorded at automatic weather stations (AWSs) using similar instrumentation. The methodology is described in detail in Schneider $(1998,1999)$.

The energy available for snowmelt, $B$, can be calculated according to:

$$
B=R+H+L+G+P .
$$

During summer an isothermal $\left(0^{\circ} \mathrm{C}\right)$ snow cover in the uppermost $2 \mathrm{~m}$ of the snowpack was found at both locations. The ground-heat flux, $G$, can therefore be neglected. The energy input from precipitation, $P$, contributed $<1 \%$ to the overall energy during the measurement period, and is therefore neglected. Net radiation, $R$, was measured with a Q-7 net radiometer (Campbell Scientific Ltd, U.K.). Temperature and humidity were measured with an HMP35 combined temperature and humidity probe (Vaisala, Finland). A correction was applied for insufficient ventilation of the radiation shields during periods with low wind speed, using solar irradiance and wind speed. Sensible-heat flux, $H$, and latent-heat flux, $L$, were computed according to the bulk aerodynamic method.

This formulation is discussed in detail by Braithwaite (1995) and Blackadar (1997):

$$
\begin{aligned}
& H=-\frac{\rho c_{\mathrm{p}} \kappa^{2} u(z)}{\left[\ln \left(\frac{z}{z_{0}}\right) \ln \left(\frac{z}{z_{0, \mathrm{H}}}\right)\right]}\left[\Theta(z)-\Theta_{0}\right](1-5 \mathrm{Rb})^{2} \\
& L=-\frac{\rho L_{\mathrm{v}} 0.622 \kappa^{2} u(z)}{p\left[\ln \left(\frac{z}{z_{0}}\right) \ln \left(\frac{z}{z_{0, \mathrm{E}}}\right)\right]}\left[e(z)-e_{0}\right](1-5 \mathrm{Rb})^{2},
\end{aligned}
$$

where $\rho$ is air density, $c_{\mathrm{p}}$ is specific heat at constant air pressure $\left(1005 \mathrm{~J} \mathrm{~kg}^{-1} \mathrm{~K}^{-1}\right), \kappa$ is the von Kármán constant $(0.4), L_{\mathrm{v}}$ is the latent heat of evaporation or sublimation ( 2.514 or $\left.2.849) \times 10^{6} \mathrm{~J} \mathrm{~kg}^{-1}\right), p$ is air pressure, $u(z)$ is wind velocity at height $z, z$ is height above snow surface $(2.0 \mathrm{~m}), z_{0}, z_{0}, \mathrm{H}$ and $z_{0}, \mathrm{E}$ are roughness lengths for momentum, heat and water vapour, respectively, $\Theta(z)$ is potential air temperature at height $z, \Theta_{0}$ is potential air temperature at the snow surface $\left(0^{\circ} \mathrm{C}\right), e(z)$ is water-vapour pressure at height $z, e_{0}$ is watervapour pressure at the snow surface $(6.1 \mathrm{hPa})$ and $\mathrm{Rb}$ is the bulk Richardson number. $\mathrm{Rb}$ is defined as

$$
\mathrm{Rb}=\frac{g\left[\Theta(z)-\Theta_{0}\right]\left(z-z_{0}\right)}{\bar{\Theta} u(z)^{2}} .
$$

This was necessary to account for the stable stratification of the boundary layer (Braithwaite, 1995) which often occurs during the summer over melting snow surfaces. A correction for unstable conditions was not applied, because such conditions were very rare during the field campaign.

The surface temperature was set to $0^{\circ} \mathrm{C}$ for time periods with air temperatures above $0^{\circ} \mathrm{C}$, and the water-vapour pressure was fixed to $6.1 \mathrm{hPa}$ assuming $100 \%$ relative humidity at the snow surface. During periods with air temperatures below zero, the gradient between measurements of humidity and temperature at $z_{1}=0.5 \mathrm{~m}$ and $z=2.0 \mathrm{~m}$ was used to calculate turbulent-energy exchange. 


\section{Inner Marguerite Bay}

$120 \mathrm{~m}$ a.s.I., $68^{\circ} \mathrm{S} / 67^{\circ} \mathrm{W}$

0

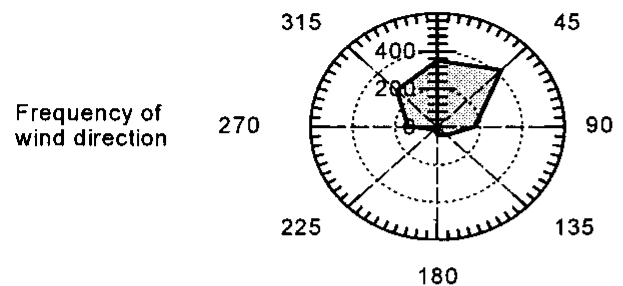

180

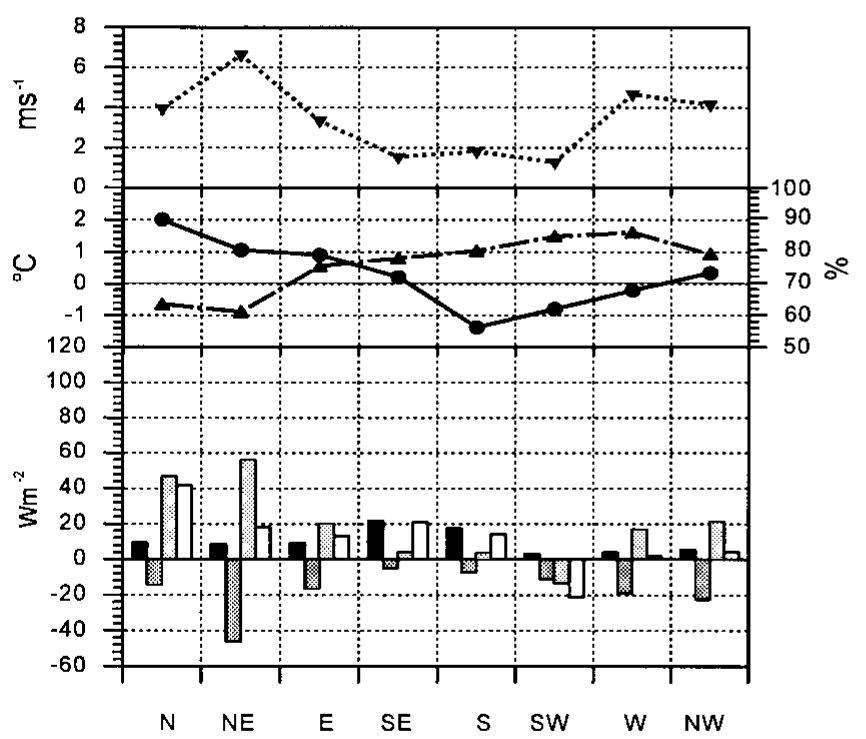

King George Island

$85 \mathrm{~m}$ a.s.I., $62^{\circ} \mathrm{S} / 58^{\circ} \mathrm{W}$

0

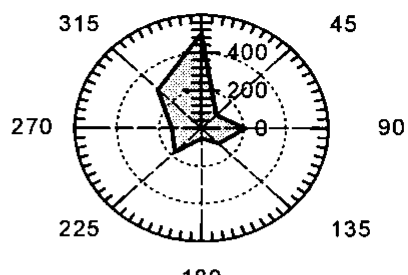

180

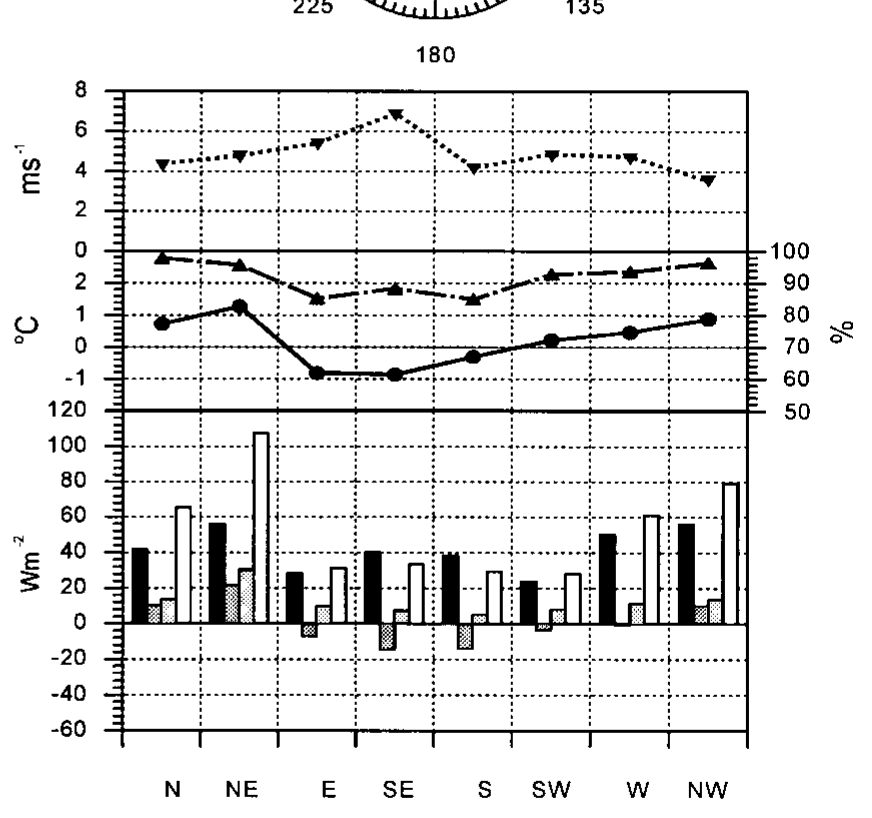

Frequency of wind direction

- Air temperature

- Rel. humidity

...-... Wind velocity

Fig. 2. Frequency of wind directions during the research periods on Northeast Glacier (left) and on King George Island (right), with plots of the mean values of wind speed, air temperature, relative humidity and the terms of the energy balance for different wind-direction classes during the periods of investigation.

The surface-roughness lengths for momentum $\left(z_{0}\right)$, heat $\left(z_{0}, \mathrm{H}\right)$ and water vapour $\left(z_{0}, \mathrm{E}\right)$ were used as tuning parameters of the model. Snowmelt observed in snow pits and measured at ablation stakes or continuously recorded by a sonic height sensor was used to "calibrate" the energybalance computations. The best fit was obtained using $z_{0}=z_{0}, \mathrm{H}=z_{0}, \mathrm{E}=5 \times 10^{-4} \mathrm{~m}$ at the King George Island test site, while $z_{0}=z_{0}, \mathrm{H}=10^{-3} \mathrm{~m}$ and $z_{0}, \mathrm{E}=10^{-5} \mathrm{~m}$ was required at the Marguerite Bay test site. Error analysis using an error-propagation model reveals that single values of the energy-balance components may suffer from errors as high as $\pm 20 \%$.

\section{RESULTS AND DISGUSSION}

The energy balance for the two study sites is summarized in Table 1. The mean albedo during the measurement period was 0.82 at both study sites (snow surface). The mean air temperatures during the periods of observation at Bellingshausen and San Martín were higher than the long-term averages. For example, the mean temperature for San Martín in January 1995 was $+3.1^{\circ} \mathrm{C}$, compared to the long-term average of $+2.2^{\circ} \mathrm{C}$ (1979-98). The corresponding value for Bellingshausen was $+2.4^{\circ} \mathrm{C}$ in January 1998 and $+1.3^{\circ} \mathrm{C}$ for the long-term aver- age (1944-98). The two energy-flux studies cannot be compared directly, since they were measured during different years. There are no long-term observations of the frequency of synoptic situations available with which to check if the two years were representative, but the temperature record at Faraday $\left(65^{\circ} 15^{\prime} \mathrm{S}, 64^{\circ} 16^{\prime} \mathrm{W}\right)$ indicates that both years were similar and close to the mean of the period 1988-98. The mean air temperature for December-February was $+1.05^{\circ} \mathrm{C}(1994 / 95),+1.1^{\circ} \mathrm{C}(1997 / 98)$ and $1.2^{\circ} \mathrm{C}$ (mean of the years 1988-98). In the following we will compare the magnitude of fluxes for the two sites.

In general, the mean of the energy available for snowmelt is higher $\left(+63 \mathrm{~W} \mathrm{~m}^{-2} ; 17 \mathrm{~mm}\right.$ w.e. $\left.\mathrm{d}^{-1}\right)$ on subantarctic King George Island than in Marguerite Bay $\left(+19 \mathrm{~W} \mathrm{~m}^{-2}\right.$; $6 \mathrm{~mm}$ w.e. $\mathrm{d}^{-1}$ ) assuming similar large-scale synoptic conditions for both years. The ratios between net radiation and turbulent-heat fluxes are also quite different: approximately 1.5 for King George Island and 0.86 for Marguerite Bay. An additional $5 \mathrm{~W} \mathrm{~m}^{-2}$ of energy is produced by condensation on the South Shetland Islands. For Marguerite Bay, however, the latent-heat transfer is an energy loss of $-25 \mathrm{~W} \mathrm{~m}^{-2}$ due to sublimation and evaporation from the snow cover according to our measurements. This value might be an overestimation, since relative humidity measurements are problematic in cold temperatures. 
Table 1. Summary of results from energy-balance studies on the Antarctic Peninsula, the South Shetland Islands and South Georgia

\begin{tabular}{|c|c|c|c|c|c|c|c|}
\hline Study site & $\begin{array}{c}\text { Research } \\
\text { period } \\
\mathrm{dd} / \mathrm{mm} / \mathrm{yy}\end{array}$ & $\begin{array}{c}\text { Radiation } \\
\text { balance } \\
\mathrm{W} \mathrm{m}^{-2}\end{array}$ & $\begin{array}{l}\text { Sensible- } \\
\text { heat flux } \\
\mathrm{W} \mathrm{m}^{-2}\end{array}$ & $\begin{array}{l}\begin{array}{c}\text { Latent- } \\
\text { heat flux }\end{array} \\
\mathrm{W} \mathrm{m}^{-2}\end{array}$ & $\begin{array}{c}\text { Sum of energy } \\
\text { fluxes } \\
\mathrm{W} \mathrm{m}^{-2}\end{array}$ & $\begin{array}{c}z_{0}, z_{0, \mathrm{H}}, z_{0, \mathrm{E}} \\
\mathrm{m}\end{array}$ & Source \\
\hline King George Island $\left(62^{\circ} \mathrm{S}, 58^{\circ} \mathrm{W}\right.$; $85 \mathrm{~m}$ a.s.l.) & $\begin{array}{c}02 / 12 / 97- \\
06 / 02 / 98\end{array}$ & $\begin{array}{l}43.5 \\
69.1 \%\end{array}$ & $\begin{array}{l}14.7 \\
23.4 \%\end{array}$ & $\begin{array}{c}4.7 \\
7.5 \%\end{array}$ & $\begin{array}{l}62.9 \\
100 \%\end{array}$ & $5 \times 10^{-4}$ & This study \\
\hline Inner Marguerite Bay $\left(68^{\circ} \mathrm{S}, 67^{\circ} \mathrm{W} ; 120 \mathrm{~m}\right.$ a.s.l. $)$ & $\begin{array}{c}20 / 12 / 94- \\
19 / 02 / 95\end{array}$ & $\begin{array}{c}8.6 \\
46.2 \%\end{array}$ & $\begin{array}{l}35.5 \\
190.8 \%\end{array}$ & $\begin{array}{l}-25.5 \\
-137 \%\end{array}$ & $\begin{array}{l}18.6 \\
100 \%\end{array}$ & $10^{-3}, 10^{-3}, 10^{-5}$ & This study \\
\hline South Georgia $\left(54^{\circ} \mathrm{S}, 36^{\circ} \mathrm{W} ; 375 \mathrm{~m}\right.$ a.s.l. $)$ & $\begin{array}{l}01 / 11 / 73- \\
04 / 04 / 74\end{array}$ & $\begin{array}{l}47.5 \\
54.8 \%\end{array}$ & $\begin{array}{l}41.6 \\
47.9 \%\end{array}$ & $\begin{array}{c}-2.3 \\
-2.7 \%\end{array}$ & $\begin{array}{l}86.8 \\
100 \%\end{array}$ & $\begin{array}{c}1.3 \times 10^{-3}, 10^{-5} \\
10^{-5}\end{array}$ & Hogg and others (1982) \\
\hline King George Island $\left(62^{\circ} \mathrm{S}, 58^{\circ} \mathrm{W} ; 100 \mathrm{~m}\right.$ a.s.l. $)$ & $\begin{array}{c}17 / 12 / 90- \\
16 / 01 / 91\end{array}$ & $\begin{array}{l}60.8 \\
63.5 \%\end{array}$ & $\begin{array}{l}27.4 \\
28.7 \%\end{array}$ & $\begin{array}{c}7.4 \\
7.8 \%\end{array}$ & $\begin{array}{l}95.6 \\
100 \%\end{array}$ & $10^{-3}$ & Bintanja (1995) \\
\hline Anvers Island ${ }^{*}\left(64.5^{\circ} \mathrm{S}, 63.5^{\circ} \mathrm{W} ; 474 \mathrm{~m}\right.$ a.s.l. $)$ & $05-16 / 02 / 82$ & $\begin{array}{l}14.5 \\
32.9 \%\end{array}$ & $\begin{array}{c}4.7 \\
10.7 \%\end{array}$ & $\begin{array}{c}24.9 \\
56.5 \%\end{array}$ & $\begin{array}{l}44.1 \\
100 \%\end{array}$ & - & Casassa (1989) \\
\hline Alexander Island $\left(71^{\circ} \mathrm{S}, 68^{\circ} \mathrm{W} ; 250 \mathrm{~m}\right.$ a.sl. $)$ & $\begin{array}{c}03 / 11 / 73- \\
31 / 01 / 74\end{array}$ & $\begin{array}{c}8 \\
20.5 \%\end{array}$ & $\begin{array}{l}32 \\
82 \%\end{array}$ & $\begin{array}{l}-1 \\
-2.5 \%\end{array}$ & $\begin{array}{l}39 \\
100 \%\end{array}$ & $10^{-3}$ & Jamieson and Wager (1983) \\
\hline
\end{tabular}

* Values estimated from figures.

In order to refine the interpretation of the energy balances at the two study sites, energy-balance terms and meteorological readings were classified in respect of the wind direction measured $2 \mathrm{~m}$ above the snow surface at the AWS (Fig. 2). Due to local topographic effects, the measured wind direction does not necessarily coincide with the synoptic-scale wind direction. Nevertheless, Figure 2 reveals interesting characteristics:

Air temperatures on King George Island are generally not much higher than at the Marguerite Bay test site. However, the relative humidity is significantly higher on King George Island, whatever the wind direction. This is in agreement with the different latent-heat fluxes at the two study sites.

In Marguerite Bay, the wind usually blows from the north. The northeasterly wind direction reflects föhntype winds across the mountains, with high mean wind velocity and low relative humidity. The latent-heat flux from the isotherm snowpack $\left(0^{\circ} \mathrm{C}\right)$ is negative under these conditions. The sensible-heat flux is enhanced due to the high mean air temperature which results from the adiabatic descent of the air.

Since the study site in Marguerite Bay is protected by an offshore island in the west (summit at $900 \mathrm{~m}$ a.s.l.), westerly air flow is measured at the AWS as wind from the northwest or north. In these weather conditions warm air is advected into Marguerite Bay. High sensible-heat flux triggers intensive snowmelt, whereas the radiation balance is of minor importance for the overall energy balance. Wind from the southern sector at low velocities occurs rarely, and can be attributed to a high-pressure ridge over the Antarctic Peninsula. During these periods the turnover of the energy balance is small and the net radiation balance dominates the energy balance.

Winds from the north and northwest prevail on King George Island. Ablation is very high during these periods because of the advection of warm and moist air masses from lower latitudes. Polar cold and dry air is advected from the south, and around the northern tip of the peninsula from the east. The southerly and easterly air flow is a consequence of the cold barrier wind origi- nating in the Weddell Sea (Schwerdtfeger, 1984). During these periods latent-heat flux shows negative values and the sensible-heat flux is very small. The radiation balance contributes most of the ablation.

In the following the results of the present study are compared with previously published data for the Antarctic Peninsula (Table 1). Again, the interannual variability might limit the conclusions that can be drawn from this comparison.

At a test site on South Georgia, Hogg and others (1982) obtained the largest sensible-heat flux $\left(+42 \mathrm{~W} \mathrm{~m}^{-2}\right)$ published for the Antarctic Peninsula. A possible explanation is higher wind speeds and the more northerly location, with higher air temperature during the summer months. The radiation balance is comparable to the values obtained on King George Island.

The ratio between turbulent heat fluxes and net radiation is similar in both studies from King George Island. Bintanja (1995) observed more energy available for snowmelt $\left(+96 \mathrm{~W} \mathrm{~m}^{-2}\right)$ than in the present study. Easterly advection of cold air masses dominated for a time period of approximately 10 days in December 1997. This could be a reason for the generally lower energy balance in this study than in Bintanja (1995). Furthermore, his test site in Admiralty Bay is characterized by lee-side effects leading to a higher mean air temperature. Enhanced input by net radiation may be attributed to the lower albedo of bare glacier ice towards the end of his field campaign.

Casassa (1989) presents an estimation of the surface energy balance for Anvers Island using bulk equations with coefficients derived from Hokkaido, Japan. Anvers Island which experiences a highly maritime climate is located in an intermediate position between the South Shetland Islands and Marguerite Bay. This can be seen from the value of the net radiation balance $\left(+15 \mathrm{~W} \mathrm{~m}^{-2}\right)$. The ratios of the turbulent fluxes are in contrast to all other studies from the Antarctic Peninsula. A possible explanation is the use of questionable transfer coefficients in the bulk equations.

Jamieson and Wager (1983) measured values of radiation balance $\left(8 \mathrm{~W} \mathrm{~m}^{-2}\right)$ and sensible-heat flux $\left(+32 \mathrm{Wm}^{-2}\right)$ similar to those in the Marguerite Bay study. Their mean value of the latent-heat flux is only $-1 \mathrm{~W} \mathrm{~m}^{-2}$ for the test site 
on Alexander Island. The large negative values found during this study due to the föhn-type winds were not reported by Jamieson and Wager (1983).

\section{GONCLUSION}

Summer snowmelt is much higher (three times higher in our study) at the test site on the South Shetland Islands than in Marguerite Bay. At both study sites, advection from the north causes the highest summer snowmelt rates. Therefore, an increased number of synoptic situations with northerly air flow, as predicted by King and Harangozo (1998), would substantially increase ablation on the Antarctic Peninsula. Precipitation will also be enhanced by an increase in northerly air flow (Turner and others 1995, 1997). This could compensate for the predicted increase of ablation.

The energy-balance components at the two test sites studied on the Antarctic Peninsula can be classified according to the predominant wind directions. For example, the ratio of the sum of sensible- and latent-heat flux and the energy available for snowmelt is higher on Northeast Glacier (0.54) than on King George Island (0.31). For our study based on different time periods (years) due to this different ratio, we speculate that the mass-balance response to climate variations is different in the north of the peninsula than in locations south of Adelaide Island. Therefore, we suggest that sensitivity studies should consider not only the mean air-temperature increase, but also possible changes in other climate parameters, such as wind speed and humidity. The frequency of synoptic circulation patterns and their impact on heat-flux components is also worth further study.

Given the difference in climate between the northern and southern Antarctic Peninsula, further energy-balance studies at additional sites would be useful. These investigations should cover total ablation seasons.

\section{ACKNOWLEDGEMENTS}

This study was financed by the German Research Foundation (DFG) (contract No. SA694/1-1) and the German Federal Secretary of Education and Research (BMBF) (contract No. 03PL016A). We would like to thank S. Meißner, F. Rau, S. Vogt, F. Weber, the crew of Base Antártica San Martín (Argentina) and J. C. Simões and his team (Brazil) for cooperation during fieldwork. The Alfred-Wegener-Institut für Polar- und Meeresforschung, the Instituto Antártico Argentino, the British Antarctic Survey and the Brazilian Antarctic Program kindly provided logistic support. We acknowledge helpful comments from K. Steffen, P. Calanca and an anonymous reviewer.

\section{REFERENCES}

Bintanja, R. 1995. The local surface energy balance of the Ecology Glacier, King George Island, Antarctica: measurements and modelling. Antarct. Sci., 7(3), 315-325.

Blackadar, A. K. 1997. Turbulence and diffusion in the atmosphere. Berlin and Heidelberg, Springer-Verlag.

Braithwaite, R. J. 1995. Aerodynamic stability and turbulent sensible-heat flux over a melting ice surface, the Greenland ice sheet. F. Glaciol., $41(139), 562-571$.

Braun, M., F. Rau, H. Saurer and H. Goßmann. 2000. Development of radar glacier zones on the King George Island ice cap, Antarctica, during aus- tral summer 1996/97as observed in ERS-2 SAR data. Ann. Glaciol., 31 (see paper in this volume).

Casassa, G. 1989. Velocity, heat budget and mass balance at Anvers Island ice cap, Antarctic Peninsula. Antarct. Rec., 33(3), 341-352.

Doake, C. S. M., H. F. J. Corr, H. Rott, P. Skvarca and N.W. Young. 1998. Breakup and conditions for stability of the northern Larsen Ice Shelf, Antarctica. Nature, 391(6669), 778-780.

Fox, A. J. and A. P. R. Cooper. 1998. Climate-change indicators from archival aerial photography of the Antarctic Peninsula. Ann. Glaciol., 27, 636-642.

Hogg, I. G. G., J. G. Paren and R. J. Timmis. 1982. Summer heat and ice balances on Hodges Glacier, South Georgia, Falkland Islands Dependencies. f. Glaciol., 28 (99), 221-238.

Jamieson, A.W. and A. C. Wager. 1983. Ice, water and energy balances of Spartan Glacier, Alexander Island. Br. Antarct. Surv. Bull. 52, 155-186.

King, J. C. 1994. Recent climate variability in the vicinity of the Antarctic Peninsula. Int. 7. Climatol., 14(4), 357-369.

King, J. C. and S. A. Harangozo. 1998. Climate change in the western Antarctic Peninsula since 1945: observations and possible causes. Ann. Glaciol., 27, 571-575.

Lucchitta, B. K. and C. E. Rosanova. 1998. Retreat of northern margins of George VI and Wilkins Ice Shelves, Antarctic Peninsula. Ann. Glaciol., $27,41-46$.

Martianov, V. and S. Rakusa-Suszczewski. 1989. Ten years of climate observations at the Arctowski and Bellingshausen stations (King George Island, South Shetland Islands, Antarctica). In Birkenmeyer, A., ed. Global change regional research centres: scientific problems and concept developments. Warsaw-Jablonna, IGBP, IASA, Unesco, 80-87. (PAS Seminar.)

Orheim, O. and L.S. Govorukha. 1982. Present-day glaciation in the South Shetland Islands. Ann. Glaciol., 3, 233-238.

Pepper, J. 1954. The meteorology of the Falkland Islands and Dependencies, 1944-1950. London, C.F. Hidgson and Son Ltd. (Falkland Islands and Dependencies Meteorological Service.)

Rachlewicz, G. 1997. Mid-winter thawing in the vicinity of Arctowski Station, King George Island. Pol. Polar Res., 18(1), 15-24.

Reynolds, J. M. 1981. The distribution of mean annual temperatures in the Antarctic Peninsula. Br. Antarct. Surv. Bull. 54, 123-133.

Rott, H., W. Rack, T. Nagler and P. Skvarca. 1998. Climatically induced retreat and collapse of northern Larsen Ice Shelf, Antarctic Peninsula. Ann. Glaciol., 27, 86-92.

Rundle, A. S. 1970. Snow accumulation and ice movement on the Anvers Island ice cap, Antarctica: a study of mass balance. International Association of Scientific Hydrology Publication 86 (Symposium at Hanover, 1968 - Antarctic Glaciological Exploration (ISAGE), 377-390.

Schneider, C. 1998. Zur raumzeitlichen Differenzierun der Energiebilanz und des Zustandes der Schneedecke auf zwei Gletschern der Marguerite Bay, Antarktische Halbinsel. Freibg. Geogr. Hefte 56.

Schneider, C. 1999. Energy balance estimates during the summer season of glaciers of the Antarctic Peninsula. Global and Planetary Change, 22(1-4), 117-130.

Schwerdtfeger, W. 1984. Weather and climate of the Antarctic. Amsterdam, Elsevier. (Developments in Atmospheric Science 15.)

Simôes, J. C., U. F. Bremer, F. E. Aquino and F. A. Ferron. 1999. Morphology and variations of glacial drainage basins in the King George Island ice field, Antarctica. Ann. Glaciol., 29, 220-224.

Skvarca, P., W. Rack, H. Rott and T. Ibarzábal y Donángelo. 1998. Evidence of recent climatic warming on the eastern Antarctic Peninsula. Ann. Glaciol., 27, 628-632.

Smith, R. C., S. E. Stammerjohn and K. S. Baker. 1996. Surface air temperature variations in the western Antarctic Peninsula region. In Ross, R. M., E. E. Hofmann and L. B. Quentin, eds. Foundations for ecological research west of the Antarctic Peninsula. Washington, DC, American Geophysical Union, 105-121. (Antarctic Research Series 70.)

Turner, J., T. A. Lachlan-Cope, J. P. Thomas and S. R. Colwell. 1995. The synoptic origins of precipitation over the Antarctic Peninsula. Antarct. Sci. 7 (3), 327-337.

Turner, J., S. R. Colwell and S. A. Harangozo. 1997. Variability of precipitation over the coastal Antarctic Peninsula from synoptic observations. $\mathcal{F}$. Geophys. Res., 102(D12), 13,999-14,007.

Wen Jiahong, Kang Jiancheng, Han Jiankang, Xie Zichu, Liu Leibao and Wang Dali. 1998. Glaciological studies on the King George Island ice cap, South Shetland Islands, Antarctica. Ann. Glaciol., 27, 105-109.

Wunderle, S. 1996. Die Schneedeckendynamik der Antarktischen Halbinsel und ihre Erfassung mit aktiven und passiven Fernerkundungsverfahren. Freibg. Geogr. Hefte 48. 